Information for citation:

Kvacheva P. I., Petrova S. V. Politiko-pravovoy status nepriznannogo gosudarstva v sovremennom mire: istoriko-pravovoy aspect (no primere Respubliki Abkhaziya) [Political and Legal Status of Unrecognized States in the Modern World: Historical and Legal Aspects (a Case Study of the Republic of Abkhazia)]. Vestnik Permskogo Universiteta. Juridicheskie Nauki - Perm University Herald. Juridical Sciences. 2017. Issue 35. Pp. 56-65. (In Russ.). DOI: $10.17072 / 1995-4190-2017-35-56-65$.

UDC 327.8

DOI: 10.17072/1995-4190-2017-35-56-65

\title{
POLITICAL AND LEGAL STATUS OF UNRECOGNIZED STATES IN THE MODERN WORLD: HISTORICAL AND LEGAL ASPECTS (A CASE STUDY OF THE REPUBLIC OF ABKHAZIA)
}

\section{P. I. Kvacheva}

Sochi State University

26a, Sovetskaya st., Sochi, 354000, Russia

ORCID: 0000-0003-2056-3815

ResearcherID: R-7521-2016

e-mail: kvacheva46@mail.ru

\author{
S. V. Petrova \\ Sochi State University \\ 26a, Sovetskaya st., Sochi, 354000, Russia \\ ORCID: 0000-0003-4626-3116 \\ ResearcherID: R-7419-2016 \\ e-mail: solus46@mail.ru
}

Introduction: the international legal institution of the right of peoples to self-determination is an integral part of the formation basis for an independent state. In the conditions of integration of state legal institutions, modern political processes in the world set a task for researchers to consider the issue of the legal status of countries that still have the status of unrecognized republics. This problem is especially critical for the regions that withdrew their membership in the Soviet Union in the course of political and military conflicts and that are now seeking for the recognition of their sovereignty. Until the middle of the 20th century the process proceeded against the background of global military conflicts, then - in the context of the struggle with colonialism. Over the last three decades, it has been mostly associated with the collapse of totalitarian regimes in the world. Purpose: to study problems of formation of the unrecognized state in the aspect of historical, political and legal processes with the account of the changing global political environment for exercise of the right of peoples to self-determination. The modern search for the optimal form of self-determination of peoples, taking into account ideas of external and internal forms, predetermines the scientific analysis of the historical political and legal practice of establishing the statehood in the territories where enjoyment of the right of peoples to self-determination is problematic; the analysis is performed by the example of the Republic of Abkhazia. Methods: the methodological basis of the research is a systemic approach, which provides a holistic view of political and legal processes in the state. In addition, comparative, structural-functional and historical approaches have been used. Results: at the present stage of the statehood development, the Republic of Abkhazia has the status of being "unrecognized", which affects its political and legal structure, characterized by a mixture of traditional and modern state and legal institutions. The state and the law in Abkhazia largely depend on the ge-

(C) Kvacheva P. I., Petrova S. V., 2017 
opolitical situation in the region and in the world, on the political systems of the nearest neighbors and strategic allies. A significant role in the formation of the Abkhazian statehood and legal system belongs to the Russian Federation, which is in the focus of Abkhazian governmental bodies' attention for the purpose of integrating into a unified economic, political and legal space. Conclusions: today, the state and legal system of the Republic of Abkhazia exists as a transitional type system, being in the process of its synchronization with the state legal system of the Russian Federation in accordance with the aim of building a sovereign state. The status of the unrecognized state makes it impossible for the Republic of Abkhazia to participate in the international processes in full and slows down the possible impact of the international legal institutions onto its state and legal system.

Keywords: sovereignty; international institutions; the right of people to self-determination; historical, political and legal processes

\title{
Information in Russian
}

\section{ПОЛИТИКО-ПРАВОВОЙ СТАТУС НЕПРИЗНАННОГО ГОСУДАРСТВА В СОВРЕМЕННОМ МИРЕ: ИСТОРИКО-ПРАВОВОЙ АСПЕКТ (НА ПРИМЕРЕ РЕСПУБЛИКИ АБХАЗИЯ)}

\author{
Статья подготовлена в рамках проекта «История российско-абхазских отношений \\ и их развитие в новейших геополитических условиях (историко-политическое исследование)» \\ при финансовой поддержке МОН РФ в рамках ГЗ (задание 2014/261 от 19.03.2014)
}

\author{
П. И. Квачева \\ Доктор юридических наук, профессор, \\ зав. кафедрой конституционного и административного права \\ Сочинский государственный университет \\ 354000, Россия, г. Сочи, ул. Советская, 26а \\ ORCID: 0000-0003-2056-3815 \\ ResearcherID: R-7521-2016 \\ e-mail: kvacheva46@mail.ru
}

\section{С. В. Петрова}

Доктор политических наук, доцент,

зав. кафедрой теории и истории государства и права

Сочинский государственный университет

354000, Россия, г. Сочи, ул. Советская, 26а

ORCID: 0000-0003-4626-3116

ResearcherID: R-7419-2016

e-mail: solus46@mail.ru

Введение: Международный правовой институт прав народов на самоопределение является неотьемлемой частью основ формирования независимого государства. Современные политические процессы в мире в условиях интеграции государственно-правовых институтов ставят перед исследователями вопрос о правовом статусе стран, которые до сих пор имеют статус непризнанных республик. Наиболее остро ощущается проблема в отношении тех регионов, которые вылли из состава Советского Союза в ходе политических и военных конфликтов, а теперь добиваются признания суверенного статуса. Но если до середины XX в. этот процесс протекал в русле мировых военных конфликтов, а потом и борьбы стран с колониализмом, то последние три десятилетия он связан чаще всего с разрушением тоталитарных режимов в мире. Цель: изучение проблемы становления непризнанного государственного образования в аспекте исторических, политических и правовых прочессов в условиях изменяющейся мировой политической конъюнктуры осуществления права народов на самоопределение. Современный поиск оптимальной формы самоопределения народов с учетом идей внешних и внутренних 
форм предопределяет научный анализ исторической политической и правовой практики формирования государственности в территориях проблемного осуществления права народов на самоопределение на примере Республики Абхазия. Методы: методологическую основу исследования составляет системный подход, позволяющий целостно рассмотреть политические и правовые прочессы, происходящие в государстве. Также используются сравнительный, структурно-функциональный и исторический подходы. Результаты: Республика Абхазия на современном этапе развития государственности находится в статусе «непризнанности», что сказывается на ее политической и правовой системе, характеризующейся смешением традиионных и модернистских государственных и правовых институтов. Государство и право в Абхазии во многом зависит от геополитической обстановки в регионе и в мире, политических систем ближайших соседей и стратегических союзников. Достаточно большую роль в прочессе формирования абхазской государственности и правовой системы играет Российская Федерачия, на которую ориентируются властные структуры Республики Абхазия в иелях интеграции в единое экономическое, политическое и правовое пространство. Выводы: государственноправовая система Республики Абхазия на сегодняшний день существует как система переходного типа, находящаяся в процессе синхронизаџии с государственно-правовой системой Российской Федераџии в соответствии с ориентацией на построение суверенного государства. Статус непризнанного государства делает невозможным полноценное участие Республики Абхазия в международных проиессах и замедляет возможность воздействия международно-правовых институтов на ее государственно-правовую систему.

Ключевые слова: суверенитет; международные институты; право народа на самоопределение; исторические, политические и правовые процессы

\section{Introduction}

The problem of the legal status of a state facing a military, national or religious conflict is currently a critical problem in the system of international relations. Unrecognized states appeal to the international organizations, such as the UN organization, and assert their right to self-determination, sovereignty and protection of their interests in the world community being guided by the international law (the United Nations Charter, Declaration of Principles of International Law of 1970, Resolution of the UN General Assembly 2625, Helsinki Final Act of 1975 and others).

Changes in the geopolitical map of the world during the period of the velvet revolutions in 19891991 in Europe and the collapse of the USSR with its of ideals of communist society construction resulted in the development of the political processes within the framework of establishing new subjects of international policy and law. This phenomenon went down in history as the parade of sovereignties of the former Soviet republics, which took place with no consideration of the territorial and status consequences for the autonomous republics [9; 13]. The national and religious contradictions that had been accumulating for years in the structure of the Soviet political and state system resulted in the inter-religious and inter-ethnic conflicts (Nagorno Karabakh, South Ossetia, Trans-Dniester, Abkhazia) in the post-Soviet space.
In the Northern Black Sea Area of the Caucasus, the conflict that led to the war of 1992-1993 between Georgia and Abkhazia resulted in territorial losses for Georgia and announcement of the sovereignty of the Republic of Abkhazia, which was reflected in its Constitution of November 26, 1994 that established the sovereign democratic principium and legal status of the Abkhazian statehood.

The issue of the Abkhazian statehood establishment is a discourse for both political and historical legal researches, which was reflected in monographs and thesis works by M. I. Zuhba [3], I. N. Bartsits [1], I. V. Bzhinava [2], S. V. Petrova [8], S. A. Kislitsin [6] and others.

The authors see the Abkhazian statehood development in the following chronology: the Abkhazian ethnogeny covered the epoch from the ancient times till joining the Russian Empire in the 19th century; revolutionary events of 1917 and the civil war of 1918-1920 allowed the Abkhazian people to declare the creation of their statehood independently of other states; in 1921-1931 Abkhazia was developing in the status of the Soviet Socialist Republic being included into the Transcaucasian Soviet Federative Socialist Republic (TSFSR) and since 1922 - within the USSR statehood; in 1931 the Republic was included into the Georgian SSR as an autonomous area. In August 1991, the Georgian Republic announced its sovereignty and withdrawal from 
the USSR, which was recorded on December 21, 1991 in the Declaration of the Union State Disbandment. Consequently, over the 20th century and in the framework of the Soviet statehood, the Abkhazian people passed through the period from the establishment of sovereignty to the loss of it. The ethnic and military conflicts that started in 19921993 between Georgia and Abkhazia after the USSR collapse, resulted in Abkhazia's declaring itself a sovereign state, thus setting grounds for the world community to view the Republic of Abkhazia as an unrecognized state entity [11].

\section{Establishment of the Modern Statehood of the Republic of Abkhazia}

After the events of the "five-day war" in 2008 and the activation of the foreign policy focus of the Russian Federation, the problem of the independence of the Republic of Abkhazia requires developing a new approach to treating the issues of the unrecognized state and its policies $[10 ; 14]$. The Republic of Abkhazia qualified the support announced by the RF political leaders as the policy of noninterference into the affairs of sovereign states and their choice as a possibility to reform the state's political system, which was reflected in the Constitution of Abkhazia of 1994 [16].

When on August 26, 2008 President Medvedev signed the Decree on Recognizing the Independence of the South Ossetia and Abkhazia, it seemed that this would remain an exception - a reply to the acknowledgement of Kosovo's independence by the West with no approval received from Russia [12]. The two recent years have demonstrated that Moscow is ready to continue supporting the course for self-determination: the annexation of Crimea, the support for the selfdeclared Lugansk People's Republic and Donetsk People's Republic, the intensification of the official contacts with Transdniester and Georgia. Lately, the activity has moved beyond the limits of the post-Soviet area. On September 20, 2016 Moscow hold international conference "Dialogue of the Nations. The Right of Peoples to SelfDetermination and Construction of the Multipolar World", which gathered representatives of separatist movements from the countries of the Western Europe and America.

The Kremlin tries to demonstrate that it is capable of being a center of gravity alternative to the West, proposing the self-determination fighters to get what is necessary for them - political, financial or military support, in parallel furthering its interests in the regions. However, the first two experi- ences (of South Ossetia and Abkhazia) show that it is not good enough at developing long-term partnership.

Russia originally gave the two republics what they needed: safety, financial and political support, and received the opportunity to have its military presence in the region - a response to the strengthening of the UNO cooperation with Georgia. Today, still being grateful to Russia for all the things done, the citizens of two republics with increasing frequency criticize the policy of Moscow, which relies on the loyalty of the elites and often ignores the population's needs.

On October 21, 2016 in Sukhumi, the block of oppositional forces gathered several thousand people and proposed president Raul Hadzhimba to step aside, accusing him in particular of the fact that "the Republic of Abkhazia is losing its state sovereignty" by descending more and more into dependence on Russia.

Abkhazia and South Ossetia totally supported the policy of Russia at the moment of their recognition: in their understanding, the West took the part of Georgia, and Russia was the only state that could protect and guarantee the social and economic stability. Russia had really accepted the responsibility for the political representation of the republics, for providing safety (having located its military facilities and border patrol there) and financing (the level of the budget support of the republics is higher than $90 \%$ for South Ossetia and $70 \%$ for Abkhazia). At the same time, conducting their own foreign policy and having their own defense agencies fundamentally differentiated the republics from the Russian regions. However, many officials in Moscow started to treat the republics as two additional constitutional territories of the Federation.

In August 2008, when Russia recognized the sovereignty of the two self-declared republics, they were headed by people having complicated relations with Moscow. In no way can Eduard Kokoity or Sergei Bagapsh be called anti-Russia politicians - the good relations were a guarantee for the survival of the republics facing a conflict with Georgia, but the first one often irritated Moscow with his speeches and actions, and the second one was elected in 2004 against the will of Russia which supported the candidature of the current president Raul Hadzhimba. Neither was the situation simpler with Alexander Ankvab: the next president elected contradictory to the Kremlin's support, as reported, refused to sign the new 
cooperation agreement with Russia in 2014, as the agreement would significantly strengthen the republic's dependence.

The actual presidents of South Ossetia and Abkhazia got into power through the support of Moscow. Now it is possible to speak about the elites not only loyal to Kremlin but in many respects integrated into the Russian vertical power structure and accountable more to Moscow rather than to their own population. And although the level of such dependence is different for Abkhazia and South Ossetia, the formula "loyalty in exchange for financing" is applicable everywhere.

Moscow's reaction to the so-called "Maidan movement" in two republics - massive protests, preceding the election of the actual leaders - was opposite. The main thing was, in all appearances, not the fact of choosing the policy at the Maidan but the absolute loyalty to the Kremlin.

During the political crisis in Abkhazia in MayJune of 2014, the high-ranking Moscow representatives - Vladimir Surkov and Rashid Nurgaliev did not prevent the opposition's protests and evicting president Ankvab from his post; and after that all the presidential candidates agreed to sign a new agreement with Russia which "would allow Moscow to consolidate its allies and strengthen its positions and authority in the new political realities after the annexation of Crimea". However, the text of the agreement that was developed last autumn and covered the cooperation and strategic partnership caused indignation in Abkhazia and was interpreted as the threat to its sovereignty, first of all due to the significant increase of the control over the local defense agencies by Russia, and also due to the necessity to harmonize the foreign policy. The agreement provided for the social and economic support of the republic, and its final version included many corrections introduced by the Abkhazian party, but the process of its enforcement turned out to be not easy. The process of making agreements between the defense agencies of Russia and Abkhazia is not moving forward: the Parliament opposition is against the agreements that limit the sovereignty in this sphere. The money promised by Moscow has not arrived - and the government does not have resources except for those intended for paying the salaries. The republic that received support from Moscow is now a hostage of Moscow's policy. Countering the criticism of the opposition, Hadzhimba said: "The situation in Russia and around is complicated due to the known circumstances. And it directly influences our position".
The agreement between Russia and Abkhazia on the combined forces was signed on November 21, 2015 in Moscow. As the document explanatory note runs, the forces are meant for responding armed attacks and other threats to the military security of any of the parties.

The combined forces include the united Russian military facility located in the territory of $\mathrm{Ab}$ khazia, two motorized rifle battalions, artillery and aviation groups and a special operations unit. In case of an aggressive threat and in case of war, the combined forces pass to the control of the commander appointed by the Ministry of Defense of Russia. The decision on the alignment of the forces is taken jointly by the military departments of both countries.

In January of 2015, the State Duma ratified the agreement between Russia and Abkhazia on the cooperation and strategic partnership. The document provides for the joint actions on protecting the Georgia-Abkhazia border and marine body covered by the sovereignty of the Republic of Abkhazia.

"The United States strongly oppose the Russian Federation ratification of the agreement secured with the de-facto leaders in Georgia's breakaway region of Abkhazia regarding a joint military force. We do not recognize the legitimacy of this so-called "treaty", which does not constitute a valid international agreement", - Kirby said.

In his opinion, "the US position concerning Abkhazia and South Ossetia remains apparent: these regions are the inherent parts of Georgia, and the USA continue to support the independence of Georgia, its sovereignty and territorial integrity". "Russia should meet all of its obligations of the ceasefire agreement of 2008", - the representative of the American foreign-policy establishment continued. He called on Moscow to return its troops to the positions they had occupied before the conflict started, to "cancel the recognition of the Georgian regions of South Ossetia and Abkhazia as independent states", and to provide the access to the humanitarian aid for the citizens of these regions.

On November 16, 2016, at its plenary meeting the Federation Council ratified the agreement on the combined military forces of Russia and Abkhazia. The document defining the purpose, the procedure of formation, deployment and usage of the joint troops of the Military Forces (MF) of Russia and Abkhazia was signed in Moscow on November 21, 2015. The RF military facilities located in the territory of Abkhazia are included into the combined forces on the part of Russia, 
while two separate motor rifle battalions, artillery and aviation group, and a separate special forces unit are included on the part of Abkhazia.

The forces are meant for "adequate responding to armed attacks (aggression) and other threats to the military security of any of the parties" - the supporting documents say. It is expected that the organization and implementation of joint actions will be performed on the basis of joint decisions of the general staffs of the MF of both parties. In peacetime, the cooperation of the military divisions is managed by the operational team consisting of representatives of the parties. The group should be headed by the commander of the Russian military facilities.

The agreement duration is till November 24, 2024 - till the period of validity of the contract on alliance and strategic partnership between the Russian Federation and Abkhazia, with the possibility of its automatic prolongation. It is specially stipulated that the agreement does not cover banding together against any third party. On November 22, the President of the Russian Federation signed the law about the agreement ratification.

Thus, the political factor is the dominating one in the country's legal system development, which is most clearly seen in the constitutional reform. This tendency is generally typical of the states being in the process of the national political and legal institutions formation.

\section{Legal System of the Republic of Abkhazia and Its Specific Features}

The Constitution of the Republic of Abkhazia of 1994 established a democratic model of arranging the state relations based on the principle of separation of powers in its classical meaning. Many scientists note $[1 ; 2 ; 4 ; 5]$ that the existence of the constitutional and legal ideology is necessary for reaching the key declared political and legal purposes in the process of the democratic legal state formation, where the human rights and freedoms and their observation determine the activities of the state. Abkhazia's public development traditionally inclines to conflicts, which is explained, as it was mentioned earlier, by the specificity of the political and ethnic development. That is why the scientific and political community often addresses the following issues: the necessity to strengthen the political potential of the parliament, the independence of the court and municipal powers, the improvement of the vertical power structure, and the strengthening of the civil society institutions.
The Republic of Abkhazia, finding itself in the status of the "unrecognized state" and constantly correlating its activities with the political, economic and information influence is forced to manoeuvre between different political forces willing to establish their geopolitical domination in the region. The only adequate way to stand against the mentioned processes is the formation of the ideology of constitutional patriotism, which supposes the creation of the legal state model in its most perfect form, capable of resisting the destructive tendencies in the region. Therefore, one needs to understand that the stronger the threat to the stability of the Republic of Abkhazia is, the higher should be the motivation resource to resist the threats and stability/security challenges through the developed constitutional legal norms and institutions ascending to the acknowledged international standards.

In the development of the statehood of peoples having complicated historic past and forced to counter challenges and threats of the surrounding world, the status of sovereignty becomes a fundamental concept that includes traditional and modern ideas of the national state and law.

The Republic of Abkhazia is following this particular way - integration of the people into a unified inseparable state, which is so far only established de-facto, with the subsequent transfer to the international recognition (de-jure). The constitutionalism of the Abkhazian state is the manifestation of patriotism, when the constitution is understood as the peace, welfare and justice guarantor through the defense of the democracy and civil rights values. The "Constitutional patriotism" makes the legal state meaningful, but each national state often tries to find its own approach to the organization of public and political life. However, there are serious problems in the Abkhazian state resulting from the contradictions between the traditional and innovative variants of the social development which are used by different political forces for their selfish purposes to legitimize their presence in the governing bodies.

The absence of a noticeable progress in public life and in life of the majority of ordinary citizens in the Republic of Abkhazia is often explained not only by the political and economic condition of the country or its natural resources but by drawbacks and imperfections of separate provisions in the Constitution of Abkhazia. Moreover, the main problem is not 
imperfectness of the legal mechanism but the fact that the political elites of the "new states" of the post-Soviet space use the Constitution not in the strict construction of its separate provisions, but applying it for their own benefit according to the principle of the political conjuncture.

Yet before the events of 2008, the ideas were suggested in the Republic of Abkhazia on the necessity to introduce changes into the Fundamental Law, especially to its part covering the establishment of the Constitutional Court $[1 ; 4 ; 5 ; 7]$. In 2005, the Constitutional Reform Committee was created, which proposed to establish a Republican Constitutional Court. In particular, the professional personal qualities and necessary competences were defined for the judge candidates. Most citizens of the republic and professional lawyers had the dominating feeling that the creation of the Constitutional Court would cardinally change the current situation, because it would make it easier to control the execution of the constitutional norms (if the Constitution norms are not followed, it is a defective Constitution and so must be changed).

The Constitution of Abkhazia is a modern legal document opening up opportunities for the progressive development in the process of establishing democratic rights and freedoms and their fundamental protection. For example, Article 11 of the Constitution (about the acknowledgement and guarantee of the human rights and freedoms) is given in a blanket manner, which means its openness for new standards in the sphere of human rights.

It seems more likely that the improvement of the situation in the social, political and economic sphere of the state is possible without a global constitutional reform, through only adopting laws and regulations aimed at the execution of the constitution. The mentioned measures can lead to a positive influence on the state administration and on the perception of the legal system by the society.

It is natural that the main problem of the legal system of the Republic of Abkhazia, the same as of the whole post-Soviet space, is providing for the operability of the Fundamental Law. If we speak about fully developed democratic states, they have a clear system of measures that do not allow for changing the Constitution in favor of the political environment (the government is reportable to the society, the powers are separated with the clear mechanism of checks and balances, the independent court is available and etc.). This is exceptionally relevant for the Republic of Abkhazia, because the methods of changing its Constitution are extremely flexible due to the political tradition that has been established in the Republic. To avoid the enshrinement of specific party interests in the Constitution, many scientists and lawyers propose to bring the constitutional norms in force five years after their adoption. This norm can limit the nonlegal factors influencing the constitutional process, as well as making changes with no connection to the current political conditions. Therefore, introducing changes into the Constitution becomes possible only in case they are socially meaningful.

At the today's phase of its development, the Republic of Abkhazia faces many difficulties which impede the full-scale realization of the Constitution. These are the developed corruption, low level of the citizens' legal awareness, low economic indicators, low status and competence of the law enforcement officials and courts. With no stabilization of the situation, all the reforms are at risk of looking good only on paper.

In accordance with this principle, the constitutional reform should provide not changes in the Constitution but constitutional modernization of the whole state mechanism.

As a result of the constitutional reform, not only amendments were introduced into the Constitution, but the Constitutional law of the Republic of Abkhazia on the judiciary was accepted, which came in force on January 1, 2017. The discussions of the amendments continued from 2010 till 2014, the last changes were introduced into the Constitution in 2016.

The legal system of the Republic of Abkhazia consists of the Fundamental Law, which establishes the presidential-parliamentary form of government, declaring the democratic regime. The constitutional order is also regulated in laws "On the Elections for the President of the Republic of Abkhazia", "On the Citizenship in the Republic of Abkhazia", "On the Cabinet of Ministers". The legal system also includes the branch codes - the Criminal Code, the Family Code, the Criminal Procedural Code, the Civil Procedural Code and others.

Consequently, on the one hand, the legal system of the Republic of Abkhazia, historically cooperates with the Russian legal system, and on the other hand, it is developing within the framework of the continental law system, but with the influence of the customary law and non-constitutional forms, 
of the political life typical of the traditional political systems (citizens meeting). A peculiar paradigm is observed in these conditions, when the tradition and the moral are the dominating sources for the law enforcement practice.

In its development process, the legal system of the Republic of Abkhazia is being actively unified with the Russian legal system and the legal system of the Eurasian Economic Community member countries. For this reason, the tasks of the political, economic and social character facing the Republic create very difficult conditions for its progress. Sometimes it can result in public conflicts and disputes. At present, the state and the political system in the Republic of Abkhazia, the same as it happens in many post-Soviet states, dominate over the limits of the legal system, which periodically causes bursts of the public indignation mentioned earlier. The Abkhazian state has an important task set before it - to eliminate the non-coincidence between the fundamentals of the national law with the prevailing customary law and the modern high standards of the law and democracy. Will the modern law models be able to assimilate into the Abkhazian society, its culture and history? That is the question which is still relevant.

The geopolitical situation around the Republic of Abkhazia has been developing as unfavorable. Besides, the situation is influenced by two important factors: on the one hand - the historically formed gravitating towards Russia and its political system, and on the other hand - educating numerous lawyers in the Russian higher educational juridical institutions focused on the corresponding law model. It has already been mentioned that during the years of the Abkhazian statehood formation a number of important normative acts were adopted, a short analysis of which shows that, to a considerable degree, they are the result of the unification with the RF legislation.

However, simultaneously with the processes described, there is still some space for the customary law development, which still has a significant influence onto the legal awareness and the legal behavior.

It is most vividly manifested during the periods of the security threats intensification and escalation of the social and political conflicts. For example, during the armed hostilities of 1991-1993, a legal norm of customary law was in force according to which it was allowed for the only son in a family not to participate in the war in order to keep the future generations of the nation safe. There are many facts known when military divisions could be only headed by persons who got military appointments and received military ranks only under the principle of achievement. The leader and ideologist of the struggle for independence V. G. Ardzinba always appealed to the public on behalf of the people and often asked the elders to bless him for struggling. Besides, it is necessary to mention the development of such a customary legal institution in Abkhazia as the Council of Elders, which has its own structure and includes different local entities tribal, rural, regional and national unions. This customary legal institution has strict election rules, which rest on the unity of the achievement and prescribed imperatives. Decisions of the Council of the Elders have their own structure regulated by customary legal norms. As a rule, they consist of an introductory part, a descriptive part, a motivation part and a resolution. It is difficult to compare them with the modern normative acts, as they are expressed in a complicated specific language appealing to the timeless values and traditions, which are vividly present in the Council's argumentation of the decision.

Nowadays there is also a legal pluralism in interpreting legal norms and their applicability. We are talking about interpretation of law from the position of the spiritual dominant ideas: respecting the elders, sanctity of remembering the ancestors, honor and dignity, priority of the Abkhazian ethnos interests, etc. In particular, the legislators still do not support the liberalization of the land legislation and do not allow one to sell land to people who are not citizens of the Republic of Abkhazia.

Therefore, it can be stated that the legal system of the Republic of Abkhazia is currently unstable: in such conditions, the state faces a vivid alternative - either the predominance of the historically authentic values embedded into the state legal forms and expressed in the existence of the peculiar law tradition and development of a separate legal system, or the legal development within the Russian law system entailing more unified features.

\section{Conclusions}

Research on the legal and political status of the Republic of Abkhazia as an unrecognized state in the modern world's system allows us to draw the following conclusions:

1. The leading factor in recognizing the Abkhazian statehood is the Russian Federation, which looks after its geopolitical interests in the region, keeping the humanitarian, socio-economic, 
cultural and of course political contacts with the Republic.

2. The duration of the conflict and the change of its political component evidence that the final recognition of the Republic of Abkhazia is only possible in the conditions of the international environment, even in case the NATO has a negative attitude toward the process.

3. The Republic of Abkhazia itself is capable of proving its right to self-determination within the framework of the international integration, due to its stable internal and external political development.

4. The current situation in the Republic of Abkhazia is characterized by a selective enforcement of the Constitution and absence of the absolute supremacy of the law in different spheres of the life of society. Consequently, there take place constant attempts to reform the Constitution, and the absence of clearly defined national legal ideology appears to be obvious.

5. Since the end of the 20th century, the Republic of Abkhazia has been forming its own legal system. This process is not completed, hence the legal system of the Republic of Abkhazia is characterized by the fragmentary nature, nonsystematicity and instability.

6. As of today, the legal system of the Republic of Abkhazia can be defined as a system of the transition type, being synchronized with the law of the Russian Federation, which brings it close to the Romano-Germanic legal family in its striving for the main purpose - to build a sovereign state with its subsequent recognition by the world community.

7. The status of the unrecognized state does not allow the Republic of Abkhazia to become a fully valid participant of the international political system, and this significantly slows down the process of the international law influence onto the legal system of the Republic. Introduction of changes into the legislation and their application in law enforcement activities will only be possible when the international legal status of the Republic of Abkhazia strengthens and, subsequently, the Republic is recognized.

\section{References}

1. Bartsits I. N. Gosudarstvennoe (konstitutsionnoe) pravo Respubliki Abkhaziya [State (Constitutional) Law of the Republic of Abkhazia]. Moscow, 2009. 412 p. (In Russ.).

2. Bzhinava I. V. Stanovlenie gosudarstvennosti Abkhazii v kontekste razvitiya nauchnoy teorii $i$ praktiki realizatsii prava narodov na samoopredelenie: avtoref. diss. kand. yurid. nauk
[The Formation of the Statehood of Abkhazia in the Context of the Development of the Scientific Theory and Practice of Implementing the Peoples' Right to Self-Determination: Synopsis of Cand. jurid. sci. diss.]. Rostov-on-Don, 2009. 32 p. (In Russ.).

3. Zukhba M. I. Problema nezavisimosti Abkhazii: istoriya i politika: avtoref. diss. kand. istor. nauk. [The Problem of the Independence of Abkhazia: History and Politics: Synopsis of Cand. histor. sci. diss.]. Krasnodar, 2012. 25 p. (In Russ.).

4. Kamkiya B. A. O probleme konstitutsionnopravovoy reformy $v$ respublike Abkhaziya: sravnitel'no-pravovoy aspekt [Problem of the Constitutional Reform in Abkhazia: Comparative Aspect]. Vestnik RUDN. Seriya: Yuridicheskie nauki - Bulletin of Peoples' Friendship University of Russia. Series Law. 2014. No. 2. Pp. 197-205. (In Russ.).

5. Kamkiya F. G. K voprosu ob osobennostyakh pravovoy sistemy Abkhazii [About the Peculiarities of the Legal System of Abkhazia]. Vestnik RUDN. Seriya: Yuridicheskie nauki-Bulletin of Peoples' Friendship University of Russia. Series Law. 2014. No. 2. Pp. 171-186. (In Russ.).

6. Kislitsyn S. A., Petrova S. V., Repinskaya O. V. Problemy prikladnoy geopolitiki Evrazii [Problems of Applied Geopolitics of Eurasia]. Moscow, 2016. 414 p. (In Russ.).

7. Loginov A. V. Evolyutsiya konstitutsionnoy yustitsii v Rossiyskoy Federatsii i Respublike Abkhazii [Evolution of Constitutional Justice in the Russian Federation and the Republic of Abkhazia]. Istoricheskie, filosofskie, politicheskie $i$ yuridicheskie nauki, kul'turologiya $i$ iskusstvovedenie. Voprosy teorii $i$ praktiki. Nauchno-teoreticheskiy i prikladnoy zhurnal Historical, Philosophical, Political and Law Sciences, Culturology and Study of Art. Issues of Theory and Practice. Scientific-Theoretical and Applied Journal. Tambov, 2015. No. 4(54). Part 2. Pp. 112-114. (In Russ.).

8. Petrova S. V. Tsivilizatsionnye i geopoliticheskie determinanty funktsionirovaniya rezhimov vlasti $i$ struktur oppozitsii na postsovetskom prostranstve Severnogo i Yuzhnogo Kavkaza: avtoref. diss. d-ra polit. nauk [Civilizational and Geopolitical Determinants of Functioning of the Regimes of Authority and Opposition Structures in the Post-Soviet North and South Caucasus: Synopsis of Dr. polit. sci. diss.]. Rostov-on-Don, 2015. 46 p. (In Russ.).

9. Shamba T. M. Abkhaziya: pravovye osnovy gosudarstvennosti i suvereniteta [Abkhazia: the Legal Basis of Statehood and Sovereignty]. Moscow, 2005. 262 p. (In Russ.). 
10. Barabanov $M$. The August War between Russia and Georgia. Moscow Defense Brief. No. 3(13). 2008. P. 11. (In Eng.).

11. Caucasus States "Still Clan-Ruled and Commit", The European Parliament Reporter says. RFE/RL Armenia Report. Available at: http://www.rferl.org/a/1347734.html (accessed: 14.12.2016) (In Eng.).

12. Cienski J. Tbilisi Admits Misjudging Russia. Financial Times. 21.08.2008. (In Eng.).

13. Diamond L. Thinking about hybrid regimes. Journal of democracy. April 2002. Vol. 13. No. 2. Pp. 56-59. (In Eng.).

14. Diamond L. Thinking about hybrid regimes // Journal of democracy. April 2002. Vol. 13, No. 2. Pp. 56-59. (In Eng.).

15. Markedonov $S$. Abkhazia between the Past and the Future. Prague. Medium Orient Information Agency. 2013. 203 p. (In Eng.).

16. Semneby $P$. The EU, Russia and the South Caucasus - Building Confidence. Available at: http:/eng.globalaffairs.ru/number/The-EU-Russia-and-the-South-Caucasus-Building-Confidence-15507 (accessed 13.12.2016). (In Eng.).

\section{References in Russian}

1. Барции И. Н. Государственное (конституционное) право Республики Абхазия. М.: Издво РАГС, 2009. 412 с.

2. Бжинава И. В. Становление государственности Абхазии в контексте развития научной теории и практики реализации права народов на самоопределение: автореф. дис. ... канд. юрид. наук. Ростов н/Д., 2009. $32 \mathrm{c}$.

3. Зухба М. И. Проблема независимости Абхазии: история и политика: автореф. дис. ... канд. ист. наук. Краснодар, 2012. 25 с.

4. Камкия Б. А. О проблеме конституционноправовой реформы в республике Абхазия: сравнительно-правовой аспект // Вестник Российского университета дружбы народов. Сер. Юридические науки. 2014. № 2. C. 197-205.

5. Камкия Ф.Г. К вопросу об особенностях правовой системы Абхазии // Вестник Рос- сийского университета дружбы народов. Сер. Юридические науки. 2014. № 2. С. 171-186.

6. Кислицьын С.А., Петрова С.В., Репинская O. В. Проблемы прикладной геополитики Евразии. М.: Ленанд, 2016. 414 с.

7. Логинов A. B. Эволюция конституционной юстиции в Российской Федерации и Республике Абхазия. Исторические, философские, политические и юридические науки, культурология и искусствоведение // Вопросы теории и практики. Научно-теоретический и прикладной журнал. Тамбов, 2015. № 4(54), ч. 2. С. 112-114.

8. Петрова C. В. Цивилизационные и геополитические детерминанты функционирования режимов власти и структур оппозиции на постсоветском пространстве Северного и Южного Кавказа: автореф. дис. ... д-ра полит. Наук / Ростов н/Д., 2015. 46 с.

9. Шамба T. М. Абхазия: правовые основы государственности и суверенитета. М.: Издво РГТЭУ, 2004. 262 с.

10. Barabanov $M$. The August War between Russia and Georgia // Moscow Defense Brief. 2008. № 3(13). P. 11.

11. Caucasus States "Still Clan-Ruled and Commit", The European Parliament Reporter says // RFE/RL Armenia Report. URL: http://www. rferl.org/a/1347734.html (дата обращения: 14.12.2016).

12. Cienski J. Tbilisi Admits Misjudging Russia // Financial Times. 21.08.2008.

13. Diamond L. Thinking about hybrid regimes // Journal of democracy. April 2002. Vol. 13, № 2. P. 56-59.

14. Giragosian R. Georgia Planning Flaws Led to Campaign Failure // Jane's Defense Weekly. 15.08.2008.

15. Markedonov S. Abkhazia between the Past and the Future. Prague. Medium Orient Information Agency. 2013. 203 p.

16. Semneby $P$. The EU, Russia and the South Caucasus - Building Confidence. URL: http://eng. globalaffairs.ru/number/The-EU-Russia-and-theSouth-Caucasus-Building-Confidence-15507 (дата обращения: 13.12.2016). 